\title{
ANALISIS HUKUM E-LITIGASI JO. PERMA NOMOR 1 TAHUN 2019 TENTANG ADMINISTRASI PERKARA DAN PERSIDANGAN DI PENGADILAN SECARA ELEKTRONIK DIHUBUNGKAN DENGAN UNDANG- UNDANG NOMOR 7 TAHUN 1989 JO. UNDANG- UNDANG NOMOR 3 TAHUN 2006 JO. UNDANG- UNDANG NOMOR 50 TAHUN 2009 TENTANG PENGADILAN AGAMA
}

\author{
Annisa \\ Mahasiswa Program Doktor Ilmu Hukum \\ Universitas Brawijaya \\ Email : ichamulyani29@gmail.com
}

\begin{abstract}
Abstrak
Penelitian ini memiliki tujuan untuk memaparkan berkenaan dengan analisi hukum e-litigasi. Persidangan dengan e-litigasi yang dasar hukumnya berupa PERMA Nomor 1 Tahun 2019 dianggap telah melampaui hukum acara yang termuat dalam Undang-Undang Nomor 7 Tahun 1989 jo. Undang-Undang Nomor 3 Tahun 2006 jo. Undang-Undang Nomor 50 Tahun 2009 Tentang Pengadilan Agama. Pnelitian ini membahas kedudukan PERMA dalam hierarki perundangundangan agar dapat diketahui posisi PERMA dan batasan PERMA dalam menyusun peraturannya.
\end{abstract}

Kata kunci: e-litigasi, PERMA, Hukum

\section{Abstract}

This study aims to analyze the law of e-litigation. Trials with e-litigation, the legal basis of which is Supreme Court Regulations (PERMA) Number 1 of 2019, are considered to have exceeded the procedural law contained in Law Number 7 of 1989 jo. Law Number 3 of 2006 jo. Law Number 50 of 2009 concerning Religious Courts. This study discussed the position of PERMA in the hierarchy of legislation in order to find out the position of PERMA and the limitations of PERMA in formulating its regulations.

Keywords: e-litigation, PERMA, Law

\section{PENDAHULUAN}

Indonesia merupakan negara hukum sesuai dengan amanat UndangUndang Dasar 1945 pasal 1 ayat (3), dengan cakupan wilayah geografisnya berupa kepulauan. Negara sebagai sebuah organisasi terbesar memiliki sebuah regulasi yang legal untuk mengatur masyarakatnya baik dalam hal public maupun privat. Hal ini dilakukan dengan alasan agar pergerakan bangsa Indonesia tidak keluar dari arah ideologisnya.

Dalam strategi ketatanegaraannya, Indonesia menganut ajaran yang dicetuskan oleh Motesquieu, dimana dalam doktrin ajaran tersebut menyebutkan 


\section{Zurnal Negara dan $\mathcal{X}$ eadilan \\ p-ISSN 2302-7010 e-ISSN 2721-9801}

bahwa kekuasaan untuk mempertahankan peraturan perundang-undangan dipegang oleh pengadilan yang independen tanpa pengaruh campur tangan dari kekuasaan legislative maupun eksekutif. ${ }^{1}$ Pengadilan-pengadilan di Indonesia terbagi menjadi 4 pilar, yakni: peradilan umum, peradilan agama, peradilan tata usaha negara; dan peradilan militer. Pengadilan-pengadilan ini dalam UndangUndang Dasar 1945 disebutkan sebagai bagian dari kekuasaan kehakiman yang diketuai oleh Mahkamah Agung. ${ }^{2}$

Dalam rangka mengikuti zaman yang serba online dan memutkhirkan pelayanan yang ada pada lembaga peradilan di bawah naungannya, Mahkamah Agung mengeluarkan sebuah terobosan baru dengan mengedepankan tiga asas peradilan utama, yakni peradilan yang cepat, transparan, dan biaya ringan. Terobosan yang dilakukan tersebut adalah dengan mengganti system administasi beracara di pengadilan yang pada mulanya manual kini menjadi berbasis online. Terobosan tersebt dikenal dengan nama system peradilan elektronik atau yang lebih dikenal dengan sistem e-litigation (persidangan).

Salah satu dasar dari hukum acara perdata adalah Undang-Undang Nomor 7 Tahun 1989 jo. Undang-Undang Nomor 3 Tahun 2006 jo. Undang-Undang Nomor 50 Tahun 2009 tentang Pengadilan Agama dan Undang-Undang Nomor 48 Tahun 2009 tentang Kekuasaan Kehakiman. Mengenai jalannya persidangan di pengadilan, Undang-Undang Nomor 48 Tahun 2009 yang tertuang di dalam Pasal 13, menyatakan bahwa: "semua sidang pemeriksaan pengadilan terbuka untuk umum kecuali undang-undang menentukan lain." Frasa 'kecuali undang-undang menentukan lain' mengindikasikan bahwa diperkenankannya sebuah persidangan menjadi persidangan yang tertutup untuk umum selama ada regulasi yang menjadi dasar terjadinya hal tersebut.

Regulasi yang menjadi lex specialis dari aturan tersebut adalah UndangUndang Nomor 7 Tahun 1989 jo. Undang-Undang Nomor 3 Tahun 2006 jo. Undang-Undang Nomor 50 Tahun 2009 yang tertulis didalam :

Pasal 68, yang berbunyi: "pemeriksaan permohonan cerai talak dilakukan dalam sidang tertutup".

Pasal 80 ayat 2, yang berbunyi: "pemeriksaan gugatan cerai dilakukan dalam sidang tertutup"

Dari dua regulasi tersebut maka dapat diketahui bahwa, segala perihal apapun yang berkaitan dengan proses pemeriksaan perkara perceraian dilakukan dalam sidang tertutup, tidak terkecuali dalam hal upaya damai.

Berkaita dengan hal yang tertera sebelumnya, terdapat beberapa hal yang disoroti oleh penulis terkait pelaksanaan PERMA Nomor 1 Tahun 2019 ini, hal ini berkaitan dengan cara pelaksanaan hukum acara persidangan yang dirasakan penulis sangat berbeda dengan pelaksanaan hukum acara yang telah disahkan di dalam Undang-Undang Nomor 7 Tahun 1989 jo. Undang-Undang Nomor 3 Tahun 2006 jo. Undang-Undang Nomor 50 Tahun 2009, salah satunya yaitu : upaya mendamaikan para pihak dalam perkara perceraian yang dilaksanakan pada setiap kali, yang mana hal tersebut berimplikasi pada tertutup dan terbukanya suatu persidangan; hal. 112

${ }^{1}$ Maria farida Indrati, Ilmu Perundang-Undangan jilid 1, (Yogyakarta: Kanisius, 2007),

${ }^{2}$ Dasar Hukum: Pasal 24 ayat (2) UUD 1945 dan Pasal 10 ayat (2) UU No. 4 Tahun 2004 jo. UU No. 48 Tahun 2009 


\section{Jurnal Negara dan Keadilan \\ p-ISSN 2302-7010 e-ISSN 2721-9801}

Untuk itu, berkaitan dengan hukum acara tersebut, proses e-litigasi dirasa tidak memiliki hubungan yang berkesesuaian dengan hukum acara yang ada, terutama dalam perkara perceraian. Hal inilah yang menjadi pertimbangan penulis untuk menulis penelitian ini dengan mempertanyakan dapatkah PERMA yang mengharuskan badan peradilan saat ini memeriksa dan mengadili suatu perkara secara elektronik mengalahkan hukum acaranya konvensional yang ada ?.

\section{METODE PENELITIAN}

Jenis penelitian ini adalah jenis penelitian hukum (legal research), dengan menggunakan metode pendekatan yang digunakan dalam penelitian ini bersifat penelitian Yuridis-Normatif. Penelitian meneliti bahan pustaka yang ada, salah satunya yakni berupa perundang-undangan dan dokumen terkait dengan menggunakan pendekatan perundang-undangan (statute approach) dilakukan dengan menelaah semua undang-undang dan regulasi yang bersangkut paut dengan isu hukum yang sedang ditangani. ${ }^{3}$ Teknik pengumpulan bahan hukum yang digunakan adalah telaah pustaka. Analisis penelitian ini mempergunakan metode analisis penelitian yang bersifat deskriptif analisis dengan pendekatan kualitatif dan teknis analisis dalam penelitian deskriptif ini menggunakan preskriptif analitis.

\section{PEMBAHASAN}

\section{Kedudukan PERMA Dari Segi Hierarki Perundang-Undangan}

Legislative act dan ececutive act merupakan salah satu bentuk dari hukum tertulis. Tidak hanya sebatas lembaga legislative dan eksekutif, lembaga pelaksana undang-undang (yudikatif) juga diberi kewenangannya sendiri untuk menetapkan aturannya sendiri, namun dengan batasan dimana hanya boleh bersifatinternal, seperti Mahkamah Agung dengan PERMA nya. ${ }^{4}$ Fungsi pengaturan (regelen) tersebut merupakan wewenang MA yang berlandaskan hukum Pasal 79 UndangUndang Nomor 14 Tahun 1985 jo. Nomor 5 Tahun 2004 jo. Undang-Undang Nomor 3 Tahun 2009 Tentang Mahkamah Agung.

Hukum haruslah mengikuti perkembangan zaman, tidak terkecuali PERMA, untuk itu PERMA hadir sebagai alternative untuk memecah kekosongan hukum atau kebuntuan dari suatu hukum acara, yang tentu pembentukan PERMA tersebut harus disertai dengan pemberian pemanfaatan bagi penegak hukum itu sendiri. Dengan tidak menghilangkan prinsip penegakan hukum yang lain, yakni keadilan dan kepastian hukum.

\section{Hierarki Peraturan Perundang-undangan Menurut Undang-Undang} Nomor 12 Tahun 2011 jo. Undang-Undang Nomor 15 Tahun 2019

Hierarki yang dimaksud dalam Undang-Undang Nomor 12 Tahun 2011 jo. Undang-Undang Nomor 15 Tahun 2019 ini adalah jenis tingkatan peraturan perundang-undangan yang berladaskan asas bahwa peraturan yang lebih tinggi mengayomi atau menaungi peraturan-peraturan yang ada dibawahnya, dimana hal

${ }^{3}$ Peter Mahmud Marzuki, Penelitian Hukum. (Jakarta: Prenadamedia Group, 2005), hal. 133.

${ }^{4}$ Jimly Asshiddiqie, Pengantar Ilmu Hukum Tata Negara, (Jakarta: Rajagrafindo Persada, 2014) hal. 140 


\section{Jurnal Negara dan Keadilan \\ p-ISSN 2302-7010 e-ISSN 2721-9801}

tersebut menyebabkan tidak boleh ada peraturan yang lebih rendah mengesampingkan atau bahkan bertentangan peraturan yang diatasnya. ${ }^{5}$

Undang-Undang Nomor 10 Tahun 2004 jo. Undang-Undang Nomor 12 Tahun 2011 jo. Undang-Undang Nomor 15 Tahun 2019 Tentang Pembentukan Peraturan Perundang-Undangan menyebutkan Pasal 7 bahwa jenis, hierarki, berdasarkan tata urutan tertingginya yaitu: Undang-undang Dasar Negara Republik Indonesia 1945; Ketetapan Majelis Permusyawaratan Rakyat; UndangUndang/Peraturan Pemerintah Pengganti Undangundang; Peraturan Pemerintah; Peraturan Presiden; Peraturan Daerah Provinsi; dan Peraturan Daerah Kabupaten/Kota

Pasal tersembut memberikan pemahaman dasar bahwa PERMA tidak termasuk dalam hierarki perundang-undangan. Namun perlu dilihat pada pasal selanjutnya yang menyatakan bahwa PERMA sebagai salah 1 peraturan yang keberadaannya diakui. Pernyataan tersebut tertuang halam Pasal 8 ayat (1) Undang-Undang Nomor 10 Tahun 2004 jo. Undang-Undang Nomor 12 Tahun 2011 jo. Undang-Undang Nomor 15 Tahun 2019 Tentang Pembentukan Peraturan Perundang-Undangan. Pengakuan status PERMA tersebut dibarengi oleh pemenuhan syarat yang termuat dalam Pasal 8 ayat (2), yakni "diperintahkan oleh peraturan yang lebih tinggi" dan "dibentuk berdasarkan kewenangan".

Frasa dibentuk berdasarkan kewenangan tersebut perlu merujuk kembali kepada fungsi dan kewenangan Mahkamah Agung dalam Undang-Undang Nomor 14 Tahun 1985 Tentang Mahkamah Agung Pasal 79 yang menyebutkan bahwa: "Mahkamah Agung dapat mengatur lebih lanjut hal-hal yang diperlukan bagi kelancaran penyelenggaraan peradilan apabila terdapat hal-hal yang belum cukup diatur dalam undang-undang ini".

Dapat disimpulkan bahwa, Mahkamah Agung diberi celah oleh undangundang dan kewenangan untuk mengisi kekosongan hukum maupun terobosan yang sesuai dengan perkembangan zaman yang berkaitan dengan penyelenggaraan peradilan itu sendiri. Peraturan yang dikeluarkan oleh Mahkamah Agung memiliki perbedaan pada peraturan yang dibuat oleh lembaga legislative pada umumnya, dimana dalam penjelasan Undang-Undang Nomor 14 Tahun 1985 Tentang Mahkamah Agung, hanya diperbolehkan untuk membuat peraturan yang berkenaan dengan hukum acara atau teknis beracara, yang sifatnya hanya mencakup lembaga dibawahnya.

\section{Kedudukan PERMA dalam Hierarki Peraturan Perundang-Undangan}

Alat analisis yang digunakan untuk menempatkan kedudukan PERMA dalam hierarki perundang-undanga adalah bisa dengan doktrin dari Hasn Nawiasky yang menyebutkan bahwa tatanan system norma terbagi menjadi 4 kelompok, yakni: Kelompok I : Staatfundamentalnorm (norma fundamental negara); Kelompok II : Staatgrundgesetz (aturan dasar/pokok negara); Kelompok III : Formell Gesetz (Undang-undang formal) Kelompok IV: Verordnung \& Autonome Satzung (aturan pelaksana \& aturan ortonom).

dari teori tersebut maka dapat ditarik sebuah kesimpulan bahwa keberadaan PERMA masuk kedalam kategori ke-4, yakni kelompok norma Verordnung \& Autonome Satzung (aturan pelaksana \& aturan ortonom), peraturan

${ }^{5}$ Lihat penjelasan Pasal 7 ayat (2) Undang-Undang Nomor 12 Tahun 2011 tentang Pembentukan Peraturan Perundang-Undangan 


\section{$\mathcal{H}$ urnal Negara dan Keadilan \\ p-ISSN 2302-7010 e-ISSN 2721-9801}

pelaksanaan dan peraturan otonom merupakan peraturan yang terletak dibawah UU yang berfungsi menyelenggarakan ketentuan dalam UU, dimana peraturan pelaksanaan bersumber dari kewenangan delegasi, sedangkan peraturan otonom bersumber dari kewenangan atribusi. ${ }^{6}$

Berkaitan dengan kewenangan delegasi dan pembentukan peraturan perundang-undangan adalah pelimpahan kewenangan membentuk suatu aturan yang dilakukan oleh peraturan yang lebih tinggi kepada peraturan yang lebih rendah, baik pelimpahan yang dinyatakan secara lugas dan tegas maupun tidak. Berbeda dengan kewenangan atribusi, kewenangan delegasi idak diberikan, melainkan diwakilkan saja. Selain itu, sifat dari kewenangan delegasi adalah sementara dalam artian selama pelimpahan tersebut masih ada. ${ }^{7}$

Pasal 79 Undang-Undang Nomor 14 Tahun 1985 tentang Mahkamah Agung yang telah diubah menjadi Undang-Undang Nomor 5 Tahun 2004 jo. Undang-Undang Nomor 3 Tahun 2009 telah memberikan kewenangan atributif kepada Mahkamah Agung untuk membentuk sendiri peraturan yang berkaitan dengan hukum acara, dengan tujuan untuk memperlacar jalannya peradilan di Indonesia. Ketentuan lain yang tertulis dalam Pasal 14 ayat (4) Undang-Undang Nomor 48 Tahun 2009 Tentang Kekuasaan Kehakiman, telah secara tegas menyatakan bahwa pengaturan lebih lanjut mengenai sidang permusyawaratan hakim diatur melalui PERMA.

Sama halnya jika keberadaan Peraturan Mahkamah Agung ini ditinjau dari segi teori norma hukum Hans Kelsen. Hans Kelsen berpendapat bahwa setiap norma, termasuk norma hukum bersifat tingkatan atau berjenjang da berlapis dalam sebuah tatanan, dimana norma hukum yang lebih rendah akan berlaku dengan catatan, norma tersebut berdasar pada norma hukum yang lebih tinggi, begitu seterusnya hingga sampai pada sebuah norma yang tidak dapat lagi ditelusuri kelanjutannya, yaitu Norma Dasar (grundnorm).

Pada setiap PERMA yang dikeluarkan oleh Mahkamah Agung senantiasa mengandung norma yang berasal dari norma yang lebih tinggi, dalam hal ini adalah Undang-Undang Nomor 14 Tahun 1985 Tentang Mahkamah Agung jo. Undang-Undang Nomor 5 Tahun 2004 jo. Undang-Undang Nomor 3 Tahun 2009. Dengan fakta ini maka Peraturan Mahkamah Agung menurut penulis masuk dalam sistem norma hukum di Indonesia.

Berdasarkan uraian sebelumnya pula, diketahui bahwa PERMA tidak masuk dalam susunan hierarki per-undang-undangan dengan alasan:

1. Mahkamah Agung diberi kewenangan yang bersifat atributif untuk menentukan sendiri peraturannya dalam rangka menegakkan system peradilan yang baik.

2. Peraturan Mahkamah Agung berisikan peraturan tentang hukum acara atau teknis beracara.

3. Peraturan Mahkamah Agung diakui dan harus dilaksanakan sepanjang tidak bertentangan dengan peraturan yang lebih tinggi dan sesuai dengan kewenangannya yang diamanatkan oleh peraturan yang lebih tinggi.

${ }^{6}$ Maria farida Indrati, Ilmu Perundang-Undangan jilid 1, (Yogyakarta: Kanisius, 2007), hal. 55

${ }^{7}$ Maria farida Indrati, Ilmu Perundang-Undangan jilid 1, (Yogyakarta: Kanisius, 2007), 


\section{Zurnal Negara dan $\mathcal{X}$ eadilan \\ p-ISSN 2302-7010 e-ISSN 2721-9801}

Berdasarkan ketiga uraian alasan tersebut diatas bahwasanya kedudukan dari Peraturan Mahkamah Agung dapat dikatakan adalah dibawah undangundang, dengan alasan atributif dan delegasi bukan dalam hierarki.

\section{Analisis PERMA Nomor 1 Tahun 2019 dikaitkan dengan Undang-Undang Nomor 7 Tahun 1989 jo. Undang-Undang Nomor 3 Tahun 2006 jo. Undang- Undang Nomor 50 Tahun 2009}

Max Waber memiliki argumentasi yang menjelaskan bahwa perkembangan hukum materil dan hukum acara mengikuti tahap perkembangan tertentu, bermula dari bentuk yang sederhana hingga tahap termaju dimana hukum disusun secara sistematis dan dilaksanakan oleh orang-orang yang memiliki kapasitas dan kompetensi dalam bidang hukum. ${ }^{8}$

Hukum acara Indonesia saat ini sedang mengalami proses transisi dari sistem konfensional (yang salah satunya di dasari oleh Undang-Undang Nomor 7 Tahun 1989 jo. Undang-Undang Nomor 3 Tahun 2006 jo. Undang-Undang Nomor 50 Tahun 2009 Tentang Pengadilan Agama) menuju sistem yang lebih modern (di dasarkan pada PERMA Nomor 1 Tahun 2019 Tentang Administrasi Di Pengadilan Yang Berbasis Elektronik yang mana PERMA ini merupakan kelanjutan dari dikeluarkannya PERMA Nomor 3 Tahun 2018).

PERMA Nomor 1 Tahun 2019 Tentang Administrasi Di Pengadilan Yang Berbasis Elektronik di bentuk atas dasar kegelisahan dari sistem (hukum acara) sebelumnya. Terdapat 3 problem utama pengadilan dengan menggunakan sistem konfensional dengan dasar Undang-Undang Nomor 7 Tahun 1989 jo. UndangUndang Nomor 3 Tahun 2006 jo. Undang-Undang Nomor 50 Tahun 2009, yaitu: Keterlambatan; Keterjangkauan; dan Integritas. Untuk itu Mahkamah Agung hadir sebagai kepala dari badan peradilan di bawahnya dengan menghadirkan PERMA Nomor 1 Tahun 2019 ini sebagai sebuah alat yang memudahkan siapa saja, baik itu dari pelaksana penegakkan keadilannya maupun dari para pihak yang sedang mencari keadilan. Hal tersebut telah berkesesuaian dengan doktrin hukum yang di gagas oleh Radbruch, bahwa hukum harus meliputi 3 item didalamnya, yakni keadilan, kemanfaatan (yang dalam hal ini dapat dirasakan dari segi, efisiensi waktu dan biaya ringan yang juga berkesesuaian dengan asas peradilan), dan kepastian hukum. ${ }^{9}$

Terdapat 2 hal yang disoroti oleh penulis terkait pelaksanaan PERMA Nomor 1 Tahun 2019 ini, hal ini berkaitan dengan cara pelaksanaan hukum acara persidangan yang sangat berbeda dengan pelaksanaan hukum acara yang telah disahkan di dalam Undang-Undang Nomor 7 Tahun 1989 jo. Undang-Undang Nomor 3 Tahun 2006 jo. Undang-Undang Nomor 50 Tahun 2009, yakni:

1. Upaya mendamaikan para pihak dalam perkara perceraian yang dilaksanakan pada setiap kali, yang mana hal tersebut berimplikasi pada tertutup dan terbukanya suatu persidangan;

2. Pembacaan putusan yang berimplikasi pada perhitungan tanggal untuk melakukan pengajuan upaya hukum ke tingkat yang lebih tinggi.

\footnotetext{
${ }^{8}$ Soerjono Soekanto, Pokok - Pokok Sosiologi Hukum, (Jakarta: Raja Grafindo Persada, 1999), hal. 90

${ }^{9}$ Fauzi Yusuf Hasibuan, Strategi Penegakan Hukum, (Jakarta: Fauzie \& Partners, 2002), hal. $39-40$
} 


\section{$\mathcal{H}$ urnal Negara dan Keadilan \\ p-ISSN 2302-7010 e-ISSN 2721-9801}

Undang-Undang Nomor 48 Tahun 2009 yang tertuang di dalam Pasal 13, menyatakan bahwa: "semua sidang pemeriksaan pengadilan terbuka untuk umum kecuali undang-undang menentukan lain."

Frasa 'kecuali undang-undang menentukan lain' mengindikasikan bahwa diperkenankannya sebuah persidangan menjadi persidangan yang tertutup untuk umum selama ada regulasi yang menjadi dasar terjadinya hal tersebut.

Regulasi yang menjadi lex specialis dari aturan tersebut adalah UndangUndang Nomor 7 Tahun 1989 jo. Undang-Undang Nomor 3 Tahun 2006 jo. Undang-Undang Nomor 50 Tahun 2009 yang tertulis didalam :

a. Pasal 68, yang berbunyi: "pemeriksaan permohonan cerai talak dilakukan dalam sidang tertutup".

b. Pasal 80 ayat 2, yang berbunyi: "pemeriksaan gugatan cerai dilakukan dalam sidang tertutup"

Dari dua regulasi tersebut maka dapat diketahui bahwa, segala perihal apapun yang berkaitan dengan proses pemeriksaan perkara perceraian dilakukan dalam sidang tertutup.

Upaya damai merupakan suatu bagian dari hukum acara yang diharuskan

oleh undang-undang. Pelaksanaan upaya perdamaian bertujuan untuk mengupayakan penyelesaian perkara melalui jalan damai dengan menasihati atau menyarankan para pihak yang pada awalnya ingin bercerai agar berpikir kembali sehingga mencabut gugatannya dan tidak terjadi perceraian.

Upaya ini dilakukan oleh hakim terhadap para pihak yang ingin bercerai pada sidang pertama pemeriksaan gugatan ataupun permohonan cerai melalui proses mediasi. Dasar dari aturan ini tertuang dalam Pasal 82 ayat 1 UndangUndang Nomor 7 Tahun 1989 jo. Undang-Undang Nomor 3 Tahun 2006 jo. Undang-Undang Nomor 50 Tahun 2009 jo Undang-Undanga Nomor 3 Tahun 2006 jo PERMA Nomor 1 Tahun 2008, yang berbunyi :

"Pada sidang pertama pemeriksaan gugatan perceraian, Hakim berusaha mendamaikan kedua pihak"

Upaya damai ini akan terus dilakukan dalam setiap persidangan sebelum suatu perkara tersebut diputuskan. Hal ini sesuai dengan Pasal Pasal 82 ayat 4 Undang-Undang Nomor 7 Tahun 1989 jo. Undang-Undang Nomor 3 Tahun 2006 jo. Undang-Undang Nomor 50 Tahun 2009 yang menyatakan:

"Selama perkara belum diputuskan, usaha mendamaikan dapat

dilakukan pada setiap sidang pemeriksaan."

Pada setiap permulaan sidang, sebelum memasuki ranah pemeriksaan pokok perkaran hakim wajib mengupayakan perdamaian antara para pihak. Upaya damai ini dilakukan dalam proses persidangan dibuka untuk umum. Kemudian, jika upaya damai tersebut gagal, maka sidang akan ditutup kembali dan dilanjutkan dengan acara pemeriksaan,

Dalam e-litigasi proses mendamaikan para pihak yang jelas dasar dilakukannya adalah Undang-Undang tidak dijalankan sebagaimana mestinya karena dalam sistem e-litigasi setiap persidangan hanya dilakukan dengan pengalihan dokumen dari pihak kepada hakim sesuai dengan jawal yang telah ditetapkan. Tidak ada upaya pendamaian para pihak dalam sidang lanjutan. Dan sistem persidangan yang dilakukan dengan sistem terbuka dan kemudian tertutup 


\section{Zurnal Negara dan $\mathcal{X}$ eadilan \\ p-ISSN 2302-7010 e-ISSN 2721-9801}

pun menjadi bias karena basis dari e-litigasi hanyalah pemeriksaan berdasarkan dokumen.

Biasnya dari keterangan sidang dilaksanakan dalam persidangan terbuka untuk umum atau tertutup untuk umum juga berimplikasi dari sah atau tidaknya putusan dari suatu perkara tersebut. Hal ini didasari pada Pasal 13 UndangUndang Nomor 48 Tahun 2009, yang berbunyi:

1. Semua sidang pemeriksaan pengadilan adalah terbuka untuk umum, kecuali undang-undang menentukan lain.

2. Putusan pengadilan hanya sah dan mempunyai kekuatan hukum apabila diucapkan dalam sidang terbuka untuk umum.

3. Tidak dipenuhinya ketentuan sebagaimana dimaksud pada ayat (1) dan ayat (2) mengakibatkan putusan batal demi hukum.

Ketentuan tentang dibuka/ditutupnya suatu acara persidangan tidak hanya pada proses upaya damai dan pemeriksaan perkara. Pembacaan putusan sebagai hasil akhir yang berkekuatan hukum inkrah pun tidak lepas dari aturan tersebut. Dalam Undang-Undang Nomor 7 Tahun 1989 jo. Undang-Undang Nomor 3 Tahun 2006 jo. Undang-Undang Nomor 50 Tahun 2009, Pasal 60 menyatakan: "penetapan atau putusan pengadilan hanya sah dan mempunyai kekuatan hukum tetap apabila diucapkan dalam sidang terbuka untuk umum".

Mengenai hal tersebut, PERMA Nomor 1 Tahun 2019 menyebutkan dalam Pasal 26 ayat 3 : "pengucapan putusan/penetapan sebagaimana dimaksud pada ayat (2) secara hukum dianggap telah dihadiri oleh para pihak dan dilakukan dalam sidang terbuka untuk umum"

Menurut penulis, frase "dianggap" tidak menjadi pembenar untuk menerapkan PERMA sebagai lex specialis dari Undang-Undang yang telah ada sebelumnya. Kata "dianggap" menurut Kamus Besar Bahasa Indonesia sendiri merupakan prasangka, pendapat, atau pandangan ${ }^{10}$, hal ini dapat membuat putusan pengadilan yang harusnya bersifat pasti, nyata, dan konkret menjadi sesuatu yang sifatnya tidak pasti.

Selain berimplikasi dengan hal tersebut di atas, hukum acara yang tertuang dalam PERMA Pasal 26 ayat (2) juga menimbulkan pertanyaan dari sisi penghitungan kalender berkaitan dengan tenggang waktu diperkenankannya para pihak yang untuk mendaftarkan putusan tersebut keupaya hukum yang lebih tinggi (banding atau kasasi). Pasal 26 ayat (2) PERMA nomor 1 Tahun 2019 berbunyi: "pengucapan putusan/penetapan sebagaimana dimaksud pada ayat (1) secara hukum dilaksanakan dengan menyampaikan salinan putusan/penetapan elektronik kepada para pihak melalui Sistem Informasi Pengadilan"

Pernyataan tersebut tidak berkesesuaian dengan petunjuk teknis yang dikeluarkan oleh Mahkamah Agung itu sendiri dengan SK MA Nomor 271/KMA/SK/XII/2019 point C2 nomor 1 yang menyatakan bahwa: "permohonan banding diajukan setelah putusan pengadilan tingkat pertama diucapkan secara elektronik dalam tenggang waktu 14 hari"

Dalam hukum acara konvensional, pengadilan melakukan persidangan dengan acara pembacaan putusan dilakukan dengan sidang terbuka, yang artinya putusan tersebut harus dibacakan dan diketahui secara umum hasil dari putusan tersebut. Hal ini tertulis dalam Undang-Undang Nomor 7 Tahun 1989 jo.

\footnotetext{
${ }^{10}$ https://kbbi.web.id/anggap diakses pada tanggal 10 Juni 2020
} 


\section{$\mathcal{H}$ urnal Negara dan Keadilan \\ p-ISSN 2302-7010 e-ISSN 2721-9801}

Undang-Undang Nomor 3 Tahun 2006 jo. Undang-Undang Nomor 50 Tahun 2009 pada Pasal 60 : "Penetapan dan putusan Pengadilan hanya sah dan mempunyai kekuatan hukum apabila diucapkan dalam sidang terbuka untuk umum"

Kemudian, putusan tersebut bisa diajukan oleh para pihak yang merasa dirugikan hak nya oleh putusan pengadilan tingkat pertama dengan upaya hukum banding. Dasar hukumnya adalah Undang-Undang Nomor 7 Tahun 1989 jo. Undang-Undang Nomor 3 Tahun 2006 jo. Undang-Undang Nomor 50 Tahun 2009 pada Pasal 61 :

"Atas penetapan dan putusan Pengadilan Agama dapat dimintakan banding oleh pihak yang berperkara, kecuali apabila undang-undang menentukan lain"

Kemudian, permohonan upaya hukum banding disampaikan secara tertilulis /lisan kepada Pengadilan Agama dalam tenggang waktu 14 hari, terhitung sejak hari pengucapan/pemberitahuan putusan kepada pihak yang berkempentingan. ${ }^{11}$ Dasar hukum dari pernyataan tersebut adalah Pasal 199 RBg yang menyatakan:

“... pemohonan itu dapat diajukan oleh seorang kuasa seperti dimaksud dalam ayat (3) pasal 147 dengan suatu surat kuasa khusus kepada panitera dalam waktu 14 hari terhitung mulai hari diucapkannya keputusan pengadilan negeri, sedangkan tenggang waktu itu adalah empat belas hari setelah putusan diberitahukan menurut pasal 190 kepada yang bersangkutan, jika ia tidak hadir pada waktu putusan diucapkan"

Penetapan hari dimulainya perhitungan dan berakhirnya dalam jangka wantu 14 hari tersebut kembali menjadi bias karena tidak ada penjamin pada tanggal berapa para pihak mengerti bunyi dari putusan yang sudah putus tersebut. Jika dimulainya penghitungan sejak diunggahnya putusan tersebut ke dalam SIPP atau dikirimnya salinan putusan tersebut via elektronik kepada para pihak, maka akan menimbulkan masalah pada prinsip keadilan jika ternyata dalam tenggang waktu tersebut para pihak atau salah satu pihak belum membaca/mengetahui isi dari putusan pengadilan tersebut.

Menurut penulis, PERMA Nomor 1 Tahun 2019 membuat trobosan dengan melampaui ketetapan hukum acara yang termuat dalam Undang-Undang tersebut, dengan menyebutkan bahwa pengucapan putusan dilaksanakan dengan penyampaian salinan putusan melalui media elektronik.

Hukum acara memang harus tumbuh seiring dengan perkembangan tertentu (Max Weber). ${ }^{12}$ Namun, walaupun sesuai dengan perkembangan zaman dengan teknologi yang dapat digunakan dan mengedepankan asas peradilan sederhana; cepat; dan biaya murah, penulis merasa peraturan ini perlu direvisi mengingat 2 point yang menjadi sorotan sangat berbeda dengan hukum acara konvensional dengan status sah nya merupakan undang-undang.

Dengan mengacu pada teori dari Radbruch pula, bahwa hukum diharapkan mampu memenuhi nilai dasarnya, yakni keadilan, kemanfaatan, dan kepastian. Tiga dasar tersebut harus berjalan beriringan agar terciptanya hukum

${ }^{11}$ Oleh Endah P. pada https://badilag.mahkamahagung.go.id/prosedur-standar/prosedurberperkara/pedoman-perilaku-hakim. Diakses pada tanggal 16 Juni 2020

${ }^{12}$ Soerjono Soekanto, Pokok - Pokok Sosiologi Hukum, (Jakarta: Raja Grafindo Persada, 1999), hal. 90. 


\section{Jurnal Negara dan $\mathcal{X}$ eadilan \\ p-ISSN 2302-7010 e-ISSN 2721-9801}

yang baik dan ideal, tidak hanya mengedepankan kemanfaatan namun menggeser keadilan dan kepastian.

\section{KESIMPULAN}

Kedudukan Peraturan Mahkamah Agung dari segi hierarki perundangundangan menurut penulis adalah:

a. Peraturan Mahkamah Agung (PERMA) masuk kedalam sistem norma hukum di Indonesia.

b. Kedudukan dari Peraturan Mahkamah Agung dapat dikatakan adalah dibawah undang-undang, dengan alasan atributif dan delegasi bukan dalam hierarki..

Terdapat beberapa acara persidangan dengan e-litigasi yang dikhawatirkan berindikasi batalnya sebuah putusan yang batal demi hukum, yakni yang berkaitan dengan acara:

a. Tidak adanya kepastian dari terbuka atau tertutupnya persidangan;

b. Frasa "dianggap" dalam PERMA yang dirasa membuat suatu putusan pengadilan yang harusnya bersifat pasti menjadi bias;

Dan juga, berkenaan dengan tidak jelasnya perhitungan tanggal untuk melakukan upaya hukum yang lebih tinggi, yang bisa saja berdampak menjadi tidak adilnya proses hukum itu sendiri.

\section{Buku}

\section{DAFTAR PUSTAKA}

Fauzi Yusuf Hasibuan. 2002. Strategi Penegakan Hukum. Jakarta: Fauzie \& Partners.

Jimly Asshiddiqie. 2014. Pengantar Ilmu Hukum Tata Negara. Jakarta: Rajagrafindo Persada. Kanisius.

Maria Farida Indrati. 2007. Ilmu Perundang-Undangan jilid 1. Yogyakarta:

Peter Mahmud Marzuki. 2016. Penelitian Hukum. Jakarta: Prenadamedia Group.

Soerjono Soekanto. 1999. Pokok - Pokok Sosiologi Hukum. Jakarta: Raja Grafindo Persada

Website

https://badilag.mahkamahagung.go.id/prosedur-standar/prosedurberperkara/pedoman-perilaku-hakim Oleh Endah P. 